Анка Рађеновић*

Филолошки факултет

Универзитет у Београду
DOI https://doi.org/10.18485/fid.2019.9.ch15

UDC 811.14'366.581

$81^{\prime} 243(497.11)$

\title{
УСВАЈАҢЕ МОРФОЛОГИЈЕ ПРОШЛИХ ГЛАГОЛСКИХ ВРЕМЕНА У ПОЧЕТНОМ УЧЕЊУ СТРАНИХ ЈЕЗИКА
}

\section{Сажетак}

С обзиром на то да временско-аспектна морфологија представља изазов у учењу страних језика уопште, а самим тим и у почетном усвајању страног језика, у овом раду осврћемо се на досадашње студије како бисмо испитали начине на које се облици претеритних времена, али и временско-аспектна морфологија уопште усвајају у раном учењу страног језика. Циљ рада је да уз осврт на аспектну хипотезу која доводи у везу семантичке вредности глагола са усвајањем морфологије глагола код деце анализирамо начин на који се приказује морфологија прошлих глаголских форми у уџбеницима за учење грчког језика као страног за децу и укажемо на сличности и разлике у њиховом представљању у уџбеницима за одрасле на А1 и A2 нивоу Заједничког референтног оквира за живе језике.

Кључне речи: прошла глаголска времена, морфологија, рано и почетно учење страног језика, аспектна хипотеза, савремени грчки језик.

\section{Увод}

Примећено је да граматичке морфеме представљају проблем како за учење матерњег језика (J1), тако и за усвајање другог/страног језика (Ј2) (в. нпр. Браун 1973; Дилеј, Берт и Крешен 1982). Велики број студија о усвајању J1 и J2 од седамдесетих година прошлог века истраживао је присуство или одсуство вербалне и номиналне флексије. Када је реч о систему глагола, пажња је посвећена развоју временско-аспектне морфологије у монолингвалном и билингвалном усвајању језика (в. нпр. Антинући и Милер 1976; Блум, Лифтер и Хавиц 1980;

*_anka_radjenovic@yahoo.com 
Шлитер 1990; Шираи и Андерсон 1995; Шираи 1998; Беренс 2001), као и усвајању Ј2 код одраслих (нпр. Робисон 1995; Бардови-Харлиг и Бергстром 1996; Слабакова 1999; 2001). Према аспектној хипотези, у неким од ових студија оспорава се то да је глаголска флексија у раном стадијуму учења примарно обележје лексичког аспекта, тј. да се њоме означава инхерентни аспект, а не деиктичко време. У усвајању Ј2 код деце, с друге стране, истраживања су усредсређена на усвајање глаголских времена и на конгруенцију (нпр. Лакшманан 1994; Гаврусева и Лардијер 1996; Грондин и Вајт 1996; Превост 1997; Паради, ЛеКор и Џенеси 1998; Хазнедар 2001; Јонин и Векслер 2002). Уз изузетак појединих студија (нпр. Род 1996; Гаврусева 2002; 2003; 2004), ретке су студије које се баве начином на који се временско-аспектна морфологија развија у усвајању Ј2 код деце (Хазнедар 2007, 384).

Блом и сарадници $(2016,387)$ наводе да се код деце јављају упорне грешке у вербалној флексији, што је доказано многим студијама (Блом и Бајен 2012; Блом, Паради и Соренсон Данкан 2012; Хазнедар и Шварц 1997; Јонин и Векслер 2002; Маринис и Хондрогиани 2010; Паради и сарадници 2008), као и то да је проучавање усвајања глаголске флексије код деце која уче $\mathrm{J} 2$ веома корисно у поређењу са децом која уче J1, јер у усвајању J1 постоји утицај синтаксичке незрелости (Векслер 1998), док је овај фактор мање релевантан за децу која усвајају J2. Закључују и то да је проучавање J2 код деце од веће користи него проучавање J2 код одраслих јер нема толико израженог утицаја J1 код деце као код одраслих.

У многим студијама се закључује да усвајање морфологије J2 може бити веома тешко за ученике, нарочито одрасле, који почињу да уче J2 после детињства (Клазен, Мартсуку и Ставракаки 2010, 502). Један од покушаја да се објасне потешкоће са усвајањем морфологије јесте идеја да граматике J2 експлицитно објашњавају флексију, али да ученици J2 не успевају да је употребе у ширем контексту (Превост и Вајт 2000, 129).

Циљ нам је да, имајући у виду све наведене чињенице, као и потешкоће са којим се одрасли ученици J2 сусрећу у усвајању морфологије глагола, а у недостатку групе деце која би могла да се прате у лонгитудиналној студији која би показала на који начин се времен- 
ско-аспектна морфологија глагола грчког језика усваја у раном добу, покушамо да на основу уџбеничког материјала претпоставимо начине на које се то чини, као и да их упоредимо са начинима на које се глаголска морфологија презентује у уџбеницима J2 за одрасле.

Као основно полазиште за било какве претпоставке и поређење узећемо аспектну хипотезу, која претпоставља да се у раним фазама усвајања језика прво глаголском морфологијом „кодирају“ инхерентне аспектне разлике, а не глаголска времена или граматички аспект (Хазнедар 2007, 385). Стога је битно објаснити разлику између граматичког и лексичког аспекта као и специфичности временско-аспектног система грчког језика.

\section{Граматички и лексички аспект}

Однос између граматике и лексике аспекта предмет је многих анализа. Тако Смит $(1997,3)$ наводи да је аспект „семантички домен темпоралне структуре ситуација (радње или стања) и њихових презентација“. Направивши јасну дистинкцију између аспекта и времена инсистира на две одвојене компоненте аспекта: начину посматрања ситуације (viewpoint type) и типу ситуације (situation type). Аспект ситуације односи се на интерну структуру ситуације, док се начин посматрања ситуације односи на начин на који је ситуација граматички представљена. Сваки аспектни тип је самосталан, али су истовремено оба типа у интеракцији пружајући на тај начин основу за укупну аспектну интерпретацију реченице.

Аспект ситуације је лексички одређен глаголом и његовим својствима, док је начин посматрања ситуације морфолошки одређен афиксима или неким другим облицима. Стога се може закључити да начин посматрања ситуације кореспондира са граматичким аспектом, док ситуациони аспект кореспондира са лексичким аспектом. Прецизности ради, термин viewpoint aspect се користи да би се објаснила опозиција перфективност- имперфективност, а термин situation aspect да би се објасниле инхерентне аспектне особине глагола (Ксидопулос 1996, 119- 120).

Истиче се такође (Салабери и Комажоан 2013, 160) да постоје два облика аспекта: лексички и граматички. У литератури (Веркуј 1999; Борик 2002; Крифка 1998) употребљавају се термини предикативни (инхерентни аспект) и граматички аспект (viewpoint aspect). Иако су пре- 
дикативни и граматички аспект две различите категорије, сви наведени аутори сматрају да их готово је немогуће одвојити једну од друге.

Предикативни аспект је заправо термин којим се у новијој литератури означава Aktionsart ${ }^{1}$ y значену у ком је развијен у йроучавағима о словенском асиекӣy. Aktionsart можемо посматрати као својство глаголског предиката и односи се на интерну темпоралну структуру радње исказане предикатом (Бах 1985 у Салабери и Комажоан 2013, 160). Овим термином се означава лексичко својство глагола, а не глагол са својим афиксима. Сматра се да управо глагол са афиксима пружа информацију о аспекту и аспектној природи предикације, али је разлика између Aktionsart-a и граматичког аспекта и даље предмет лингвистичких расправа када је реч о разлици између предикативног и граматичког аспекта (Салабери и Комажоан 2013, 160).

Граматички аспект, с друге стране, односи се најчешће на извршење радње смештене у прошлост. Уколико је радња целовита, окарактерисаћемо је као перфективну, а уколико није завршена или целовита, биће окарактерисана као имперфективна. Граматички аспект, пошто није деиктичка категорија, модификује радњу која се вршила у прошлости на основу њене свршености или несвршености (Салабери 2003, 164-165). Овакав став везан је за све оне језике који, попут грчког, не разликују аспект у презентским облицима глагола.

Отуда налазимо код аутора попут Цангалидиса (1999) тврдње које се своде на то да се већина одредби глаголског вида заснива на значењским критеријумима, али се такође аспект везује и за морфолошке карактеристике, док употреба свршеног или несвршеног вида зависи и од синтаксичког избора говорника. Другим речима, употреба перфективног или имперфективног глаголског вида зависи од многобројних фактоpa, као што су, на пример, жеља говорника да прикаже глаголску радњу као целину или да нагласи њено трајање. Други фактори који утичу на овај избор јесу временске одредбе, значење речи и лексички аспект (Холтон, Мекриџ и Филипаки-Ворбартон 2004).

1 Термин Aktionsart пореклом је из немачког језика и у лингвистичкој литератури се користи за означавање лексичког аспекта. 


\section{Усвајање аспекта у Ј1 и J2: аспектна хипотеза}

Једна од најранијих студија о усвајању морфологије времена и аспекта јесте Браунова студија о усвајању енглеског као матерњег језика (Браун 1973). Браун је открио да се прогресивни аспектни маркер -ing, прва морфема која се јавља код деце која усвајају енглески као J1, никада не употребљава код глагола стања. Такође је приметио да деца користе морфологију прошлих глаголских времена са малом групом пунктуалних глагола (fell, broke) (Браун 1973, 334).

У другој лонгитудиналној студији (Блум, Лифтер и Хафиц 1980) радили су са групом четворогодишњака чији је матерњи језик такође енглески. Слично Брауну (1973), и они су открили да се употреба глаголске морфологије везује за лексички аспект. Морфема -ing јављала се готово увек са глаголима (play и run), -ed и суплетивни облици за прошлост јављали су се уз завршно-свршене глаголе (find и fall), што указује на везу временско-аспектног маркирања и инхерентних темпоралних својстава (тј. лексичког аспекта).

У експерименталној студији са децом узраста 3-8 година чији је матерњи језик француски, Бронкарт и Синклер (1973) указали су на то да ова деца прибегавају употреби облика passé composé (перфективног прошлог времена) за радње са јасним крајем и резултатом, а облике презента за радње у процесу. Закључили су да је разлика између резултата и процеса можда једино аспектно својство у говору деце чији је J1 француски.

Слично резултатима ове студије, Антинући и Милер (1976) су указали на то да је употреба облика за перфективну прошлост ограничена на глаголе постигнућа (fall и break). Интересантно је то што њихови испитаници нису користили глаголе активности и стања уз passato prossimo (перфективна прошлост) већ уз imperfetto (имперфективна прошлост).

Све наведене студије указују на то да је рана употреба временско-аспектних маркера ограничена на лексичку аспектност глагола. Овај образац усвајања довео је до развоја неколико теоријских модела у вези са раним усвајањем морфологије, од којих је најзаступљенија аспектна хипотеза у усвајању и Ј1 и Ј2 (Хазнедар 2007, 387-388).

Према аспектној хипотези, морфологија претеритних времена се не испољава са свим глаголским предикатима у исто време, већ њена употреба зависи од лексичког (инхерентног) аспекта. Тако Ан- 
дерсен и Шираи $(1994,133)$ сматрају да ће на ученика страног језика утицати семантички аспект при усвајању темпоралних и аспектних маркера везаних за глагол којим је исказана глаголска радња.

Ова хипотеза може се разложити на четири подврсте, а подела се заснива на вези граматичког и лексичког аспекта (Вендлерове категорије) (Вендлер 1957):

1. Ученици прво користе перфективне маркере за прошлост за глаголе постигнућа и остваривања, што се евентуално може проширити и на глаголе радње и стања.

2. У језицима у којима постоји опозиција перфективност/ имперфективност, имперфективна прошлост се јавља касније него перфективна, а маркирање имперфективности почиње од глагола стања, па се проширује на глаголе радње, затим на глаголе остваривања и коначно и на глаголе постигнућа.

3. У језицима са прогресивним аспектом, маркирање прогресивности почиње са глаголима радње, па се потом проширује на глаголе постигнућа и остваривања.

4. Маркери за прогресивност проширују се на глаголе стања (Бардови-Харлиг 2002, 130).

Према аспектној хипотези, морфологија глагола уско је везана за његова инхерентна својства, тј. за аспект, па се на основу ове хипотезе, на пример, облици аориста прво користе уз теличне и пунктуалне глаголе, а имперфекат уз глаголе стања и радње (Андерсен и Шираи 1994; Килштед 2002, 332-333).

Слично резултатима студија о усвајању временско-аспектне морфологије у J1, ране студије о усвајању аспекта у J2 осамдесетих и деведесетих година 20. века указују на везу лексичког аспекта и временско-аспектне морфологије. На основу података о усвајању шпанског као J2 од стране говорника чији је J1 енглески, Андерсен (1991) увиђа да се перфективни облици јављају пре имперфективних. Док је редослед у усвајању перфективне прошлости био постигнућа, остваривања, радње и стања, редослед у усвајању имперфективне прошлости је стања, радње, остваривања и постигнућа.

И студије које се односе на усвајање енглеског као J2 такође доводе у везу лексички аспект и временско-аспектну морфологију. Бардови-Харлиг и Рејнолдс (1995) указали су на то да је ученицима J2 
много теже да употребе прошло време за глаголе радње и стања него за глаголе постигнућа. Робисон (1995), Андерсен и Шираи (1994), Бардови-Харлиг (Бардови-Харлиг 2002) сматрају да усвајање морфологије глагола у раним фазама не зависи од аспектних својстава глагола. Овакво мишљење пак указује на то да инхерентна аспектна својства глагола имају улогу у усвајању и да ученици усвајају аспектне разлике пре временских. Овај став познат је као „првенство“ аспектне хипотезе, на основу ког ученици прво употребљавају временске маркере за исказивање аспекта (Андерсен и Шираи 1994, 533).

\section{Особености аспекта и претеритних времена грчког језика}

Иако су време и аспект одвојене категорије, немогуће је о њима одвојено говорити, јер се налазе у чврстој вези и међусобној интеракцији. Управо ова чињеница веома је битно полазиште за проучавање прошлих глаголских времена у савременом грчком језику.

У грчком језику аспектну разлику немогуће је приметити у презенту, већ се она остварује само у будућем и прошлом времену, због тога што се презентском основом исказује имперфективност, а аористном перфективност. Стога примећујемо да се семантика перфективног аспекта и презента у грчком међусобно искључују јер перфективни аспект подразумева да се радња извршила. У претеритним временима грчки разликује перфективни и имперфективни аспект, где се перфективни аспект користи за свршене, целовите радње, док се имперфективни аспект користи за радњу која се понавља у прошлости или радњу којом се исказује хабитуалност или трајање у прошлости (Холтон, Мекриџ и Филипаки-Ворбартон 2004). Обележје индикатива прошлих времена је аугмент, који се јавља код једносложних глагола, а почиње консонантом.

Малчуков (2009 у Хогевег, де Хуп и Малчуков 2009, 2) доказује да перфективни аспект и презент могу да коегзистирају ослањајући се на њихову коегзистенцију у словенским језицима. То се може илустровати примерима из српског језика:

Петар сваки дан чит̄а неку књигу.

Петар сваки дан $\bar{u} р о ч и \bar{u} а$ неку књигу. 
С друге стране, у савременом грчком није могуће употребити оба вида у презенту:

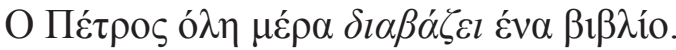

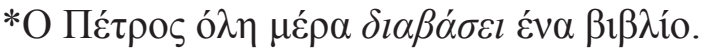

Претеритна времена у савременом грчком језику су перфекат, аорист, имперфекат и плусквамперфекат.

Грчки спада у групу pro-drop језика, што значи да може да има нулти субјекат и сваки глаголски облик маркиран је лицем, бројем, временом, аспектом и начином (Холтон, Мекриџ и Филипаки-Ворбартон 2004). Поред развијене парадигме конгруенције, грчки је специфичан по томе што не поседује облик инфинитива. Сви суфикси су силабички, у једнини моносилабички, а у множини двосилабички.

И поред овакве сложености глаголског система грчког језика, студије о усвајању конгруенције субјекта и предиката грчког као J1 указују на то да морфолошке грешке нестају пре треће године (Дукас и Маринис 2012; Катис 1984; Варлокоста, Ваиника и Рорбахер 1998). Резултати спроведених студија указују на то да се прво усваја треће лице једнине, потом прво лице једнине и то пре друге године. Друго лице једнине је облик који се усваја годину дана након усвојена претходно наведена два лица. Свакако се облици једнине усвајају пре облика множине, где се друго лице множине најкасније усваја.

Све ове особености грчког временско-аспектног система навели су истраживаче да се баве усвајањем глаголске флексије не само у J1, већ и у раном и почетном учењу грчког као J2.

Досадашње студије нарочито су усмерене на проучавање перфективне прошлости, јер је она морфолошки маркирана и разликује морфолошки правилне и неправилне облике. Наиме, правилни облици су обележени афиксом -c- (сигма) који уноси одређену фонолошку промену завршног суфикса основе и такав облик се назива сигматски, за разлику од облика који у прошлости не добијају овај афикс, па се због тога називају асигматским облицима (Клазен, Мартсуку и Ставракаки 2010, 503).

Тако су на пример Ставракаки и Клазен (2008) проучавали перфективна прошла времена код одраслих и деце нативних говорника грчког и открили три фазе развоја. Деца узраста три до четири године 
слабије су употребљавала и сигматске и асигматске облике прошлих времена, док су деца од пет до седам година употребљавала сигматске облике претеритних времена као одрасли, а имала су потешкоћа са употребом несигматских облика. Након седме године деца су потпуно равноправно као одрасли употребљавала и једне и друге облике.

Агатопулу и Пападопулу (2009) истраживале су перфективну маркираност прошлих времена код ученика грчког као J2, а резултати студије показали су да су говорници грчког као J1 или J2 више употребљавали сигматске у односу на асигматске облике (Клазен, Мартсуку и Ставракаки 2010, 504).

Поред наведених студија које се везују за имперфективну прошлост, постоји и студија која је везана за шири контекст. Наиме, Блом и сарадници (2016) истаживали су варијацију у усвајању глаголске флексије код деце којима су холандски и грчки J2, а ови језици су одабрани на основу богате флексије као једног од релевантних фактора. Основне претпоставке ове студије су те да ће се несвршени облици усвојити пре свршених, треће лице пре других лица, прво лице пре другог и једнина пре множине. Када је реч о претераној употреби одређених облика, предвиђа се да ће се несвршени облици употребљавати у свршеном контексту, треће лице уместо других лица, прво лице када треба да се употреби друго и облици једнине уместо облика за множину (Блом и сарадници 2016, 388).

\section{Временско-аспектна морфологија у ушбеницима грчког као J2 у раном и почетном учењу језика}

На основу претходно приказане теорије о раном усвајању J2 и студија које су се бавиле истраживањем усвајања временско-аспектне морфологије у J1 и J2 у раном узрасту, анализирали смо начин на који је морфологија глагола приказана у почетном уџбенику грчког

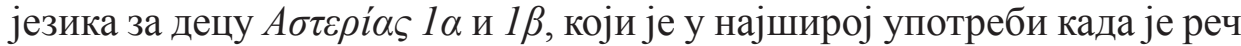
о учењу грчког као J2. Поредили смо начин на који је временско-аспектна морфологија у овом уџбенику приказана у односу на новије

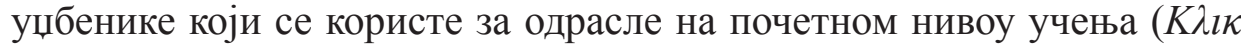
$\sigma \tau \alpha \varepsilon \lambda \lambda \eta v \iota \kappa \alpha \dot{\alpha}, T \alpha \xi i \delta l \sigma \tau \eta v E \lambda \lambda \alpha \dot{\delta} \delta \alpha$ 1) који су конципирани тако да одговарају захтевима комуникативне методе учења страног језика. 
Пошто студије о усвајању J2 у значајној мери подржавају аспектну хипотезу, претпоставили смо да ће се аутори уџбеника за децу и одрасле ослонити на претходна истраживања Ј2 како би постепено уводили облике почевши од оних који се брже уче идући ка сложенијим структурама и теже усвојивим морфолошким формама.

У анализираним уџбеницима за одрасле, сходно очекивањима, прво се постепено уводе облици презента (прва и друга конјугација, а затим и облици презента депонентних глагола), где је презентска основа описана као носилац значења трајања и понављања, насупрот аористној основи којом се у грчком језику исказује целовитост и перфективност глаголске радње. Тек након усвајања презентских облика у уџбеницима за одрасле на А1 и А2 нивоу Заједничког европског референтног оквира за живе језике (ЗЕРОЈ) уводе се облици којима се означава перфективност глаголске радње (свршени конјунктив, свршени императив, свршени футур, аорист) различитим редоследом.

За разлику од уџбеника за одрасле, у уџбеницима за децу индикатив презента уводи се преко облика императива са аористном основом, од које се граде перфективни и финитни облици претеритних времена, попут облика аориста, перфекта и плусквамперфекта. Претпостављамо да се на овај начин на основу значења глагола у везу доводе различите глаголске основе и облици који се од њих граде, али због различитих основа код глагола са суплетивним формама може да дође до забуне и непрепознавања значењске везе међу облицима (нпр. глагол $\lambda \dot{\varepsilon} \omega$ са презентском основом $\lambda \varepsilon$ - и аористном основом $\pi$-). Иако је овакав начин приказивања индикатива презента преко аористне основе неуобичајен, објашњење за овакво увођење морфологије глагола може бити то да је форма императива најчешће коришћена форма у уџбеницима за рани и почетни узраст јер постоји низ активности које треба извршити, а све су исказане императивом, па је та форма деци блиска и због тога аналогијом може бити доведена у везу са другим облицима истог глагола.

Пошто је већ на самом почетку, приликом упознавања са морфологијом глагола, дете упознато са обликом императива и његовом основом, којом се исказује перфективност, у уџбенику се приказује основно прошло време - аорист, као време које означава радњу која се догодила 
„јуче“ уз приказ глагола са сигматском основом, и на тај начин се прати след на који указују и студије којима је доказано да се облици сигматског аориста као фреквентнији раније усвајају у односу на несигматске. На основу одређених парадигми закључује се и код којих глагола долази до промене сигме у основи, што се може предвидети на основу завршног консонанта основе, а начин на који је овај феномен приказан у уџбенику за децу истоветан је начину на који се приказује у уџбеницима за одрасле. Истовремено са аористом приказан је и футур свршени, који се гради од исте (аористне) основе и презентских наставака.

Поред активних облика аориста, у истом уџбенику уводе се и три групе медио-пасивних облика овог времена са потпуно различитим наставцима, као и облици помоћних глагола и суплетивне глаголске форме аориста.

\section{Закључци}

Овим радом постављено је неколико питања у вези са усвајањем временско-аспектне морфологије у раном усвајању грчког језика као J2, узимајући у обзир резултате досадашњих истраживања, која су значајно допринела схватању начина и редоследа усвајања глаголских форми како у раном узрасту, тако и код одраслих ученика J2.

Увидели смо да је временско-аспектна морфологија у уџбенику за рано учење грчког као Ј2 приказана на веома сличан начин као и у уџбеницима за одрасле на почетном нивоу учења. У уџбеницима за децу, као и у уџбеницима за одрасле систематично се уводе облици претеритних времена, што се може поткрепити и резултатима претходних студија које указују на то да се прво усвајају финитни облици, па самим тим је за грчки специфично усвајање аористне основе којом је та финитност исказана, те је аорист прво и основно прошло време које се усваја како у раном узрасту, тако и код одраслих. Такође се овим потврђују и основна начела аспектне хипотезе, али и нераздвојивост аспекта и времена у савременом грчком језику.

Још једна особеност грчког глаголског система огледа се у приказивању прво сигматског, а потом асигматског аориста, што такође потврђује хипотезу о усвајању сигматских (,правилних“) облика пре асигматских. 
Приказивањем облика аориста и аористне основе истовремено се усваја перфективни аспект, што иде у прилог чињеници да деца веома рано схватају појмове аспекта и времена и потврђује то да деца прво усвајају лексички аспект, који касније условљава одабир граматичког аспекта (Бар-Шалом 2002, 335-336).

Без обзира на начин на који је временско-аспектна морфологија приказана у уџбеницима, она готово увек представља проблем и за децу и за одрасле ученике J2 нарочито у синтаксичкој употреби (Клазен, Мартсуку и Ставракаки 2010, 522). Стога је у наставној пракси веома важно померити фокус са језичке структуре на употребу облика у контексту. Дилеј и Берт $(1974,135)$ сматрају парадоксалним то да се и деца и наставници фокусирају на језичку структуру, а да већина оног што се научи заправо се научи ван учионице и да постоји природан ток у усвајању одређених форми без експлицитних објашњења, што код деце, али и код одраслих, може условити боље резултате.

Упоређивање начина на који је представљена временско-аспектна морфологија у уџбеницима за децу и одрасле на почетном нивоу учења грчког језика као J2 само је скроман покушај да се увиде одређене законитости за увођење глаголских облика (нарочито облика претеритних времена) у наставу, као и временски след њиховог усвајања. Да би се извели општи закључци и дошло до законитости у процесу усвајања глаголских категорија и облика неопходно је спровести емпиријска истраживања која би потврдила или оповргла претпоставке и резултате досадашњих студија.

\section{Библиографија}

Извори

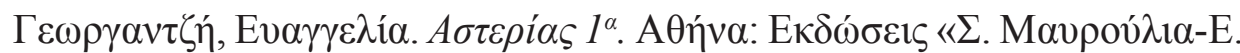

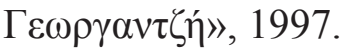

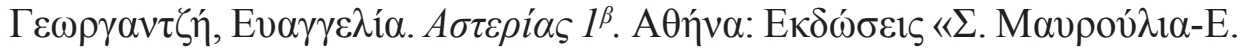

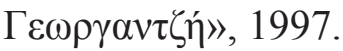




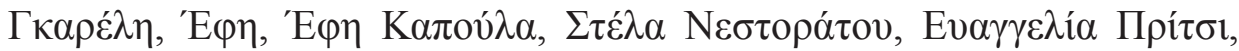

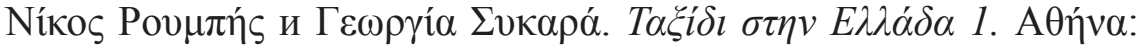

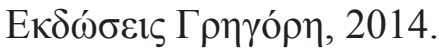

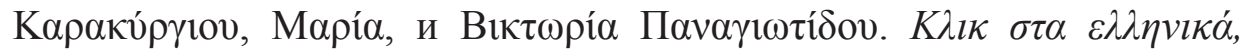

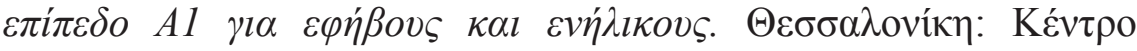
$\varepsilon \lambda \lambda \eta v i \kappa \eta ́ \varsigma ~ \gamma \lambda \omega ́ \sigma \sigma \alpha \varsigma, ~ 2014$.

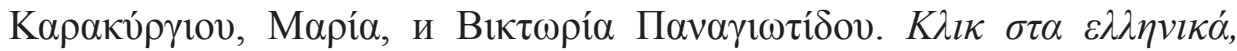

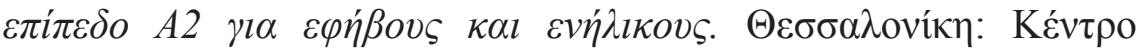

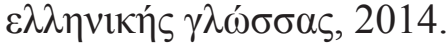

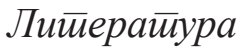

Агатопулу и Пападопулу 2009: Eleni Agathopoulou; Despina Papadopoulou. "Morphological dissociations in the L2 acquisition of an inflectionally rich language." EUROSLA Yearbook 9. Amsterdam: Benjamins.

Андерсен 1991: Roger Andersen. "Developmental Sequences Developmental sequences: The emergence of aspect marking in second language acquisition." Cross Currents in Second Language Acquisition and Linguistic Theory Language Acquisition and Language Disorders: 305-325.

Андерсен и Шираи 1994: Roger W. Andersen; Yasuhiro Shirai. "Discourse motivations for some cognitive acquisition principles." Studies in Second Language Acquisition 16 (2): 133-156.

Антинући и Милер 1976: Francesco Antinucci; Ruth Miller. "How children talk about what happened." Journal of Child Language 3 (2): $167-189$.

Бар-Шалом 2002: Eva Bar-Shalom. "Tense and aspect in early child Russian.” Language Acquisition 10 (4): 321-337.

Бардови-Харлиг 2002: Kathleen Bardovi-Harlig. “Analyzing aspect.” In Tense-aspect Morphology in L2 Acquisition, edited by Rafael Salaberry and Yasuhiro Shirai, 129-154. Amsterdam/Philadelphia: John Benjamins.

Бардови-Харлиг и Бергстром 1996: Kathleen Bardovi-Harlig; Anna Bergström. "Acquisition of tense and aspect in second language and 
foreign language learning: Learner narratives in ESL and FFL." $\mathrm{Ca}$ nadian Modern Language Review 52 (2): 308-330.

Бардови-Харлиг и Рејнолдс 1995: Kathleen Bardovi-Harlig; Dudley W.

Reynolds. "The role of lexical aspect in the acquisition of tense and aspect." TESOL Quarterly 29 (1): 107-131.

Беренс 2001: Heike Behrens. "Cognitive-conceptual development and the acquisition of grammatical morphemes: The development of time concepts and verb tense." In Language Acquisition and Conceptual Development, edited by Melissa Bowerman, 450-474. Cambridge University Press.

Блом и Бајен 2012: Elma Blom; Harald R. Baayen. "The impact of verb form, sentence position, home language, and second language proficiency on subject-verb agreement in child second language Dutch." Applied Psycholinguistics 34 (4): 777-811.

Блом и сарадници 2016: Elma Blom; Vasiliki Chondrogianni; Theodoros

Marinis; Nada Vasić. "The acquisition of verbal paradigms in Dutch and Greek L2 children: Cross-linguistic differences and inflectional defaults." International Journal of Bilingualism 20 (4): 386-402.

Блом, Паради и Соренсон Данкан 2012: Elma Blom; Johanne Paradis;

Tamara Sorenson Duncan. "Effects of input properties, vocabulary size, and L1 on the development of third person singular -sin child L2 English.” Language Learning 62 (3): 965-994.

Блум, Лифтер и Хафиц 1980: Lois Bloom; Karin Lifter; Jeremie Hafitz.

"Semantics of verbs and the development of verb inflection in child language." Language 56 (2): 386-412.

Борик 2002: Olga Borik. Aspect and Reference Time. Utrecht: LOT. Браун 1973: Roger Brown. A First Language: The early stages. Cambridge, MA: Harvard University Press.

Бронкарт и Синклер 1973: J. P. Bronckart; H. Sinclair. "Time, tense and aspect." Cognition 2 (1): 107-130.

Варлокоста, Ваиника и Рорбахер 1998: Spyridoula Varlokosta; Anne Vainikka; Bernhard Rohrbacher. "Functional projections, markedness, and "root infinitives" in early child Greek." The Linguistic Review 15 (2-3): 187-208.

Векслер 1998: Ken Wexler. "Very early parameter setting and the unique checking constraint: A new explanation of the optional infinitive stage." Lingua 106 (1-4): 23-79. 
Вендлер 1957: Zeno Vendler. "Verbs and times." The Philosophical Review 66 (2): 143-160.

Веркуј 1999: Henk Verkuyl. Aspectual Issues: Studies on Time and Quantity. Stanford University, USA: Center for the Study of Language and Information.

Гаврусева 2002: Elena Gavruseva. "Is there primacy of aspect in child L2 English?" Bilingualism: Language and Cognition 5 (2): 109-130.

Гаврусева 2003: Elena Gavruseva. "Aktionsart, aspect, and the aquisition of finiteness in early child grammar." Linguistics 41 (4): 723-755.

Гаврусева 2004: Elena Gavruseva. "Root infinitives in child second language English: An aspectual features account." Second Language Research 20 (4): 335-371.

Гаврусева и Лардијер 1996: Elena Gavruseva; Donna Lardiere. "The emergence of extended phrase structure in child L2 acquisition." In Proceedings of the 20th Annual Boston University Conference on Language Development, edited by A. Stringfellow, D. CahanaAmitay, E. Hughes, and A. Zukowski, 225-236. Somerville, MA: Cascadilla Press.

Грондин и Вајт 1996: Nathalie Grondin; Lydia White. "Functional categories in child L2 acquisition of French." Language Acquisition 5 (1): $1-34$.

Дилеј и Берт 1974: Heidi C. Dulay; Marina K. Burt. "Errors and strategies in child second language acquisition." TESOL Quarterly 8 (2): 129-136.

Дилеј, Берт и Крешен 1982: Heidi C. Dulay; Marina K. Burt; Steven Krashen. Language Two. New York: Oxford University Press.

Дукас и Маринис 2012: Thomas Doukas; Theodoros Marinis. "The acquisition of person and number morphology within the verbal domain in early Greek." Language Studies Working Papers 4: 15-25.

Јонин и Векслер 2002: Tania Ionin; Kenneth Wexler. "Why is 'is' easier than '-s'?: Acquisition of tense/agreement morphology by child second language learners of English." Second Language Research 18 (2): 95-136.

Катис 1984: Demetra Katis. The Acquisition of the Modern Greek Verb: With special reference to the imperfective past and perfect classes. Master's thesis. 
Килштед 2002: Maria M. Kihlstedt. "Reference to past events in dialogue." In The L2 Acquisition of Tense-Aspect Morphology, edited by Raphael Salaberry and Yasuhiro Shirai, 323-362. Amsterdam: John Benjamins.

Клазен, Мартсуку и Ставракаки 2010: Harald Clahsen; Maria Martzoukou; Stavroula Stavrakaki. "The perfective past tense in Greek as a second language." Second Language Research 26 (4): 501-525.

Крифка 1998: Manfred Krifka. "The origins of telicity." In Events and Grammar, edited by S. Rothstein, 197-235. Alphen aan den Rijn: Kluwer Academic Publishers.

Ксидопулос 1996: Georgios Ioannis Xydopoulos. Tense, Aspect and Adverbials in Modern Greek. PhD diss., University of London.

Лакшманан 1994: Usha Lakshmanan. Universal Grammar in Child Second Language Acquisition: Null subjects and morphological uniformity. Amsterdam: John Benjamins.

Маринис и Хондрогиани 2010: Theodoros Marinis; Vasiliki Chondrogianni. "Production of tense marking in successive bilingual children: When do they converge with their monolingual peers?" International Journal of Speech-Language Pathology 12 (1): 19-28.

Паради и сарадници 2008: Johanne Paradis; Mabel L. Rice; Martha Crago; Janet Marquis. "The acquisition of tense in English: Distinguishing child second language from first language and specific language impairment." Applied Psycholinguistics 29 (4): 363-392.

Паради, ЛеКор и Џенеси 1998: Johanne Paradis; Mathieu Le Corre; Fred Genesee. "The emergence of tense and agreement in child L2 French." Second Language Research 14 (3): 227-256.

Превост 2004: Philippe Prévost. "The semantic and aspectual properties of child L2 root infinitives." In The Acquisition of French in Different Contexts: Focus on functional categories, edited by Philippe Prévost and Johanne Paradis, 305-331. Amsterdam: John Benjamins.

Превост и Вајт 2000: Philippe Prévost; Lydia White. "Missing surface inflection or impairment in second language acquisition? Evidence from tense and agreement." Second Language Research 16 (2): 103-133.

Робисон 1995: R. E. Robison, "The aspect hypothesis revisited: A crosssectional study of tense and aspect marking in interlanguage." $A p$ plied Linguistics 16 (3): 344-370. 
Род 1996: Andreas Rohde. "The aspect hypothesis and the emergence of tense distinctions in naturalistic L2 acquisition." Linguistics 34 (5): $1115-1137$.

Салабери 2003: Rafael Salaberry. "Tense aspect in verbal morphology." Hispania 86 (3): 559-573.

Салабери и Комажоан 2013: Rafael Salaberry; Llorenç Comajoan. Research Design and Methodology in Studies on L2 Tense and Aspect. Boston: De Gruyter Mouton.

Слабакова 1999: Roumyana Slabakova. "The parameter of aspect in second language acquisition." Second Language Research 15 (3): 283-317.

Слабакова 2001: Roumyana Slabakova. Telicity in the second language. Amsterdam: John Benjamins.

Смит 1997: Carlota Smith . The Parameter of Aspect. Dordrecht: Kluwer Academic Publ.

Ставракаки и Клазен 2008: Stavroula Stavrakaki; Harald Clahsen. “The perfective past tense in Greek child language." Journal of Child Language 36 (1): 113-142.

Хазнедар 2001: Belma Haznedar. "The acquisition of the IP system in child L2 acquisition." Studies in Second Language Acquisition 23: $1-39$.

Хазнедар 2007: Belma Haznedar. "The acquisition of tense-aspect in child second language English." Second Language Research 23 (4): 383-417.

Хазнедар и Шварц 1997: Belma Haznedar; Bonnie Schwartz. "Are there optional infinitives in child L2 acquisition?" Proceedings of the 21st Annual Boston University Conference on Language Development, edited by Elizabeth Hughes, Mary Hughes, and Annabel Greenhill, 257-268. Somerville, MA: Cascadilla Press.

Хогевег, де Хуп и Малчуков 2009: Lotte Hogeweg; Helen De Hoop; Andrej Malchukov. "The semantics of tense, aspect and modality in the languages of the world." Linguistik Aktuell/ Linguistics Today Cross-linguistic Semantics of Tense, Aspect, and Modality, edited by Lotte Hogeweg, Helen De Hoop, and Andrej Malchukov, 1-12. Amsterdam: John Benjamins Publishing Company.

Холтон, Мекриџ и Филипаки-Ворбартон 2004: David Holton; Peter Mackridge; Irini Philippaki-Warburton. Greek: A comprehensive grammar of the modern language. London/New York: Routledge. 
Цангалидис 1999: Anastasios Tsangalidēs. Will and Tha: A comparative study of the category future. Thessalonikē: University Studio Press. Шираи 1998: Yasuhiro Shirai. "The emergence of tense-aspect morphology in Japanese: Universal predisposition?” First Language 18 (54): 281-309.

Шираи и Андерсен 1995: Yasuhiro Shirai; Roger W. Andersen. "The acquisition of tense-aspect morphology: A prototype account." Language 71 (4): 743-762.

Шлитер 1990: Suzanne Schlyter. "The acquisition of tense and aspect.” In Two First Languages: Early grammatical development in bilingual children, edited by Jürgen M. Meisel, 87-121. Berlin: De Gruyter Mouton.

\title{
Anka Rađenović
}

\section{THE ACQUISITION OF THE PAST TENSE MORPHOLOGY IN EARLY FOREIGN LANGUAGE LEARNING}

\begin{abstract}
Summary
Taking into account that tense-aspect morphology is challenging in learning foreign languages in general and especially in the early foreign language acquisition, in this paper we review previous studies to examine the ways in which the past tense forms and tense-aspect morphology are acquired in early foreign language learning. The aim of the paper is to analyse the ways in which the morphology of past tense forms is presented in the textbooks for learning Modern Greek as a foreign language for children considering the aspectual hypothesis which connects semantic features of the verb to the verbal morphology. We analyse perceived similarities and differences in the way the past tense verbal morphology is presented in the textbooks for adult learners at the A1 and A2 levels of the Common European Framework of Reference for Languages.
\end{abstract}

Key words: past tenses, morphology, early and beginners' foreign language learning, aspectual hypothesis, Modern Greek language. 